\title{
Thermal analysis, Raman spectroscopy and complex impedance analysis of $\mathrm{Cu}^{2+}$-doped KDP
}

\author{
Houda Ettoumi • Youping Gao • Mohamed Toumi • \\ Tahar Mhiri
}

Received: 16 March 2013 / Revised: 2 May 2013 / Accepted: 26 May 2013 /Published online: 13 June 2013

(C) The Author(s) 2013. This article is published with open access at Springerlink.com

\begin{abstract}
Raman spectroscopy and differential thermal analysis (DTA) and thermogravimetric analysis have been carried out on $\mathrm{Cu}$-doped $\mathrm{KH}_{2} \mathrm{PO}_{4}(\mathrm{Cu}-\mathrm{KDP})$. X-ray diffraction powder data reveal that the structure of the KDP crystal does not change with the additive $\mathrm{Cu}^{2+}$ ion. DTA analysis and Raman study of $\mathrm{Cu}-$ $\mathrm{KDP}$ as a function of temperature reveal that this compound undergoes two phase transitions at about $\mathrm{Ttr}=453$ and $473 \mathrm{~K}$. The electrical conductivity measurements on polycrystalline pellet of $\mathrm{Cu}-\mathrm{KDP}$ (5) are performed from room temperature (RT) up to $495 \mathrm{~K}$. Only one phase transition is observed at $470 \mathrm{~K}$. The activation energy in the migration is $0.42 \mathrm{eV}$ in the temperature range from RT to $470 \mathrm{~K}$. For temperature above $470 \mathrm{~K}$, the activation energy of the superprotonic phase is $1.87 \mathrm{eV}$.
\end{abstract}

Keywords Phase transformation - Raman spectroscopy · Dielectric properties

\section{Introduction}

The KDP family compounds $\left(\mathrm{MH}_{2} \mathrm{PO}_{4} ; \mathrm{M}=\mathrm{K}, \mathrm{Cs}, \mathrm{Rb}, \mathrm{NH}_{4}\right)$ are interesting for many reasons [1-6]. In particular, $\mathrm{CsH}_{2} \mathrm{PO}_{4}$ (CDP ) as a fuel cell electrolyte at temperatures so-called superprotonic behaviour present an abrupt, several-order-ofmagnitude jump in its proton conductivity upon heating above the temperature Ttr $\approx 508 \mathrm{~K}$ [7]. It is demonstrated that the abovementioned proton conductivity enhancement is associated with

H. Ettoumi $(\bowtie) \cdot$ M. Toumi $\cdot$ T. Mhiri

Laboratoire de L'Etat Solide (LES), Faculté des Sciences

de Sfax, Université du Sfax, Route de Soukra Km 3.5,

BP 802, 3018, Sfax, Tunisia

e-mail: ettoumihouda@yahoo.fr

Y. Gao

Laboratoire des Oxydes et Fluorures, Université du Maine,

CNRS UMR 6010, Avenue O. Messiaen,

72085 Le Mans, France a polymorphic phase transition from its room temperature monoclinic $\left(\mathrm{P}_{1} / \mathrm{m}\right)$ phase to a high-temperature dynamically disordered cubic (Pm-3m) CDP modification [8]. Interestingly, the $\mathrm{RbH}_{2} \mathrm{PO}_{4}$ (RDP) compound also exhibits a superprotonic transition at $566 \mathrm{~K}$, although at room temperature RDP is not monoclinic as CDP, but tetragonal (I $\overline{4} 2 \mathrm{~d})$. Using synchrotron X-ray studies, Botez et al. [8] demonstrated that heating RDP towards its superprotonic transition leads to an intermediate temperature $(\mathrm{Ttr}=383 \mathrm{~K})$ change of the RDP tetragonal phase into a monoclinic modification, isomorphic (crystallographically identical) to the monoclinic CDP phase. There is another phosphate, $\mathrm{NH}_{4} \mathrm{H}_{2} \mathrm{PO}_{4}$, which crystallizes at room temperature in tetragonal space group $\mathrm{I} \overline{4} 2 \mathrm{~d}$ and upon heating does not show an abrupt enhancement of its proton conductivity [9].

Much less is understood about the structural, chemical and physical property changes that occur in $\mathrm{KH}_{2} \mathrm{PO}_{4}(\mathrm{KDP})$ upon heating from room temperature toward its melting point. Thermal events observed around $\mathrm{Ttr}=458 \mathrm{~K}$, for example, have been attributed by some authors to a polymorphic phase transition at an intermediate-temperature KDP modification [10], while others have claimed that the behaviour at Ttr was in fact due to chemical changes, such as dehydration and onset of partial polymerization of the room temperature of tetragonal KDP phase [11, 12].

Previous investigations of the structural changes of KDP have been devoted, in the past few years, to understand the exact nature of this transition in KDP, which remained a controversial subject. Using X-ray diffraction measurements, Itoh et al. [13] concluded that on heating through $460 \mathrm{~K}$, the crystal system changed from tetragonal to monoclinic, space group $\mathrm{P} 2{ }_{1}$ or $\mathrm{P} 2{ }_{1} / \mathrm{m}$. The lattice parameters at $468 \mathrm{~K}$ were given as $a=7.47 \AA, b=7.33 \AA, c=14.49 \AA, \alpha=\beta=90^{\circ}$ and $\gamma=92.2^{\circ}$. The spots in the Weissenberg photograph at $468 \mathrm{~K}$ were only consistently indexed by assuming a twin structure in the monoclinic phase appearing above $460 \mathrm{~K}$. The complete assignment of the reflections was difficult to do, and until now detailed 
Table 1 Different concentrations determined by atomic absorption analysis, with a weight error of $2 \%$

\begin{tabular}{ll}
\hline & Concentration of samples $(\mathrm{mg} / \mathrm{g})$ \\
\hline $\mathrm{Cu}-\mathrm{KDP}(1)$ & 0.57 \\
$\mathrm{Cu}-\mathrm{KDP}(2)$ & 0.75 \\
$\mathrm{Cu}-\mathrm{KDP}(3)$ & 1.21 \\
$\mathrm{Cu}-\mathrm{KDP}(4)$ & 2.49 \\
$\mathrm{Cu}-\mathrm{KDP}(5)$ & 3.02
\end{tabular}

structural analyses including atomic coordinates have not been done [11]. Moreover, it has been reported that the monoclinic phase of KDP is metastable at temperatures below Ttr and that it reverts to the stable tetragonal phase after being kept for some days in air at room temperature [10, 12-14]. Very recently, temperature-resolved synchrotron X-ray studies have demonstrated that heating KDP towards its superprotonic transition leads to an intermediate temperature ( $\operatorname{Ttr}=463 \mathrm{~K})$, where the KDP tetragonal phase changes into a monoclinic phase, the same as both isomorphic monoclinic RDP and CDP [15]. Moreover, they observed that monoclinic KDP is stable up to $508 \mathrm{~K}$ and indicated that a monoclinic $\left(\mathrm{P} 2{ }_{1} / \mathrm{m}\right)$-cubic $(\mathrm{Pm} 3 \mathrm{~m})$ transition upon further heating similar to the one responsible for the superprotonic behaviour of CDP and RDP is not precluded. They concluded that the reported lack of superprotonic behaviour in KDP [16] was most likely due to ion size effects and not due to crystal structure considerations.

In view of these results, it appears that further investigations aimed to clarify the structural changes undergone by KDP upon heating above Ttr are worth carrying out.

It is well known that the presence of a small amount of impurities can considerably influence the growth habit, optical properties and dielectric properties of KDP crystals [17-21].

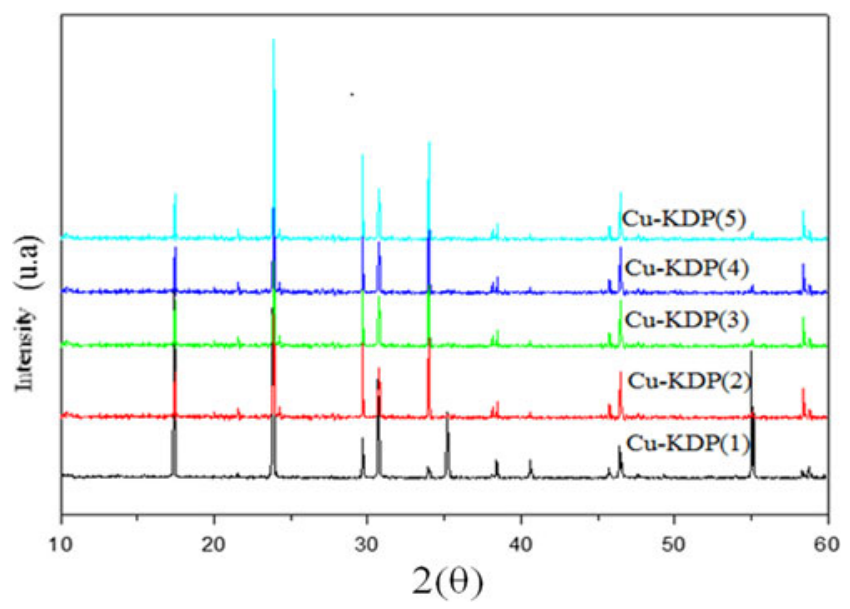

Fig. 1 The XRD patterns of $\mathrm{Cu}-\mathrm{KDP}(1), \mathrm{Cu}-\mathrm{KDP}(2), \mathrm{Cu}-\mathrm{KDP}(3)$, $\mathrm{Cu}-\mathrm{KDP}(4)$ and Cu-KDP (5)

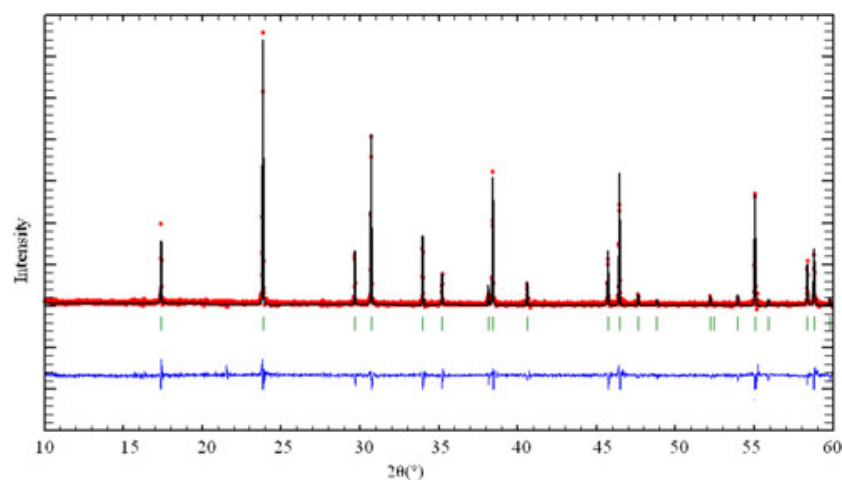

Fig. 2 The Pawley refinement of the lattice parameters of Cu-KDP (5). The point symbols represent the observed diffraction pattern, the solid lines represent the calculated pattern and the curves at the bottom of the figure represent the difference between the observed and calculated patterns. The short vertical lines mark the positions of possible Bragg reflections

Due to various physicochemical properties, impurities can be selectively incorporated at the surface of the crystal layer and into the kink sites. The presence of metallic impurities may form both isolated and interstitial defect centres [22].

This work presents the evolution of the Raman spectra of single crystal of pure KDP and $\mathrm{Cu}^{2+}$-doped KDP (Cu-KDP) when the temperature is raised from 303 to $503 \mathrm{~K}$. Raman scattering method has been successfully used to reveal structural information about a wide variety of inorganic compounds: phosphate solid acids [23, 24] and sulfate [18, 25, 26]. In particular, Raman spectroscopy is used to demonstrate the effect of heating on the partial decomposition of KDP [25, 27]. Thus, this method is suitable for the present investigation, which presents also the influence of bivalent $\mathrm{Cu}^{2+}$ impurity ions on the electrical properties.

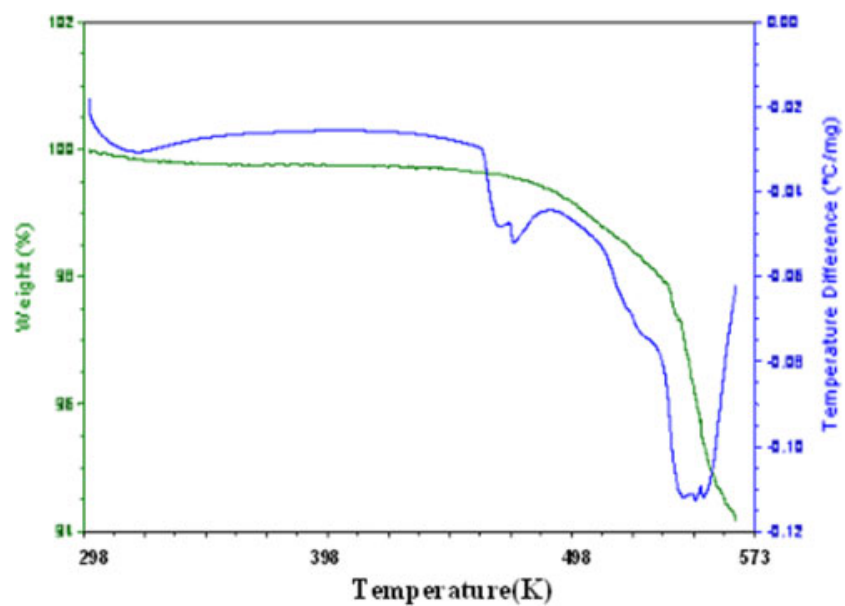

Fig. 3 Thermograms of DSC and TGA for $\mathrm{Cu}-\mathrm{KDP}$ in the room temperature $-573 \mathrm{~K}$ range 


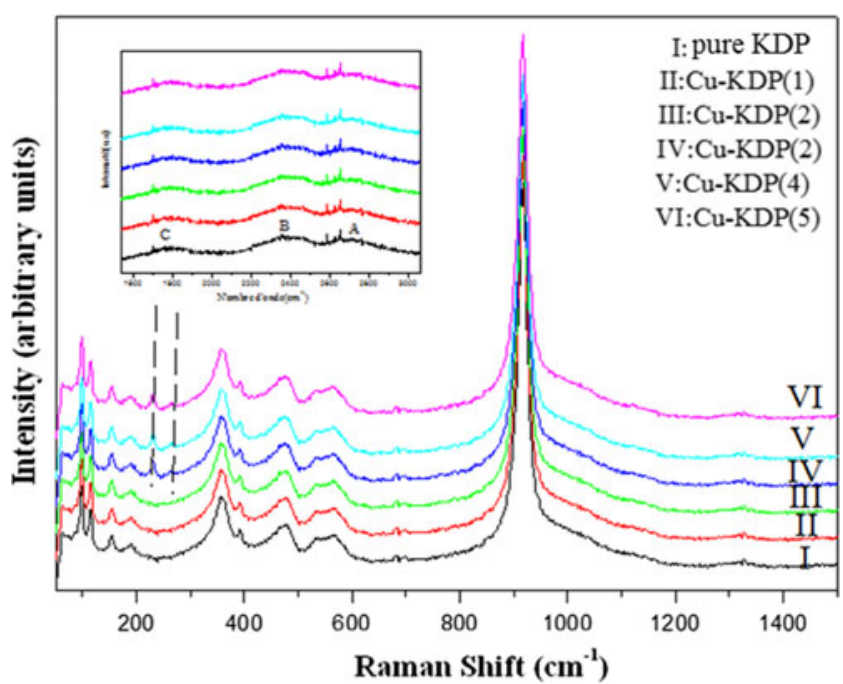

Fig. 4 Raman spectra for the pure KDP, Cu-KDP (1), Cu-KDP (2), $\mathrm{Cu}$ $\mathrm{KDP}(3), \mathrm{Cu}-\mathrm{KDP}(4)$ and $\mathrm{Cu}-\mathrm{KDP}(5)$ at room temperature

\section{Experimental details}

Five samples, Cu-KDP (1), Cu-KDP (2), Cu-KDP (3), CuKDP (4) and Cu-KDP (5), were prepared. Each sample was prepared by slow evaporation of $20 \mathrm{ml}$ of a saturated aqueous solution of KDP containing, respectively, $0.5,0.75,1,1.5$ and $2 \mathrm{~g}$ of $\mathrm{Cu}(\mathrm{OH})_{2}$. The concentration is determined by atomic absorption analysis, with a weight error of $2 \%$ (Table 1 ).

Figure 1 compares the XRD patterns of $\mathrm{Cu}-\mathrm{KDP}(1), \mathrm{Cu}-$ $\mathrm{KDP}(2), \mathrm{Cu}-\mathrm{KDP}(3), \mathrm{Cu}-\mathrm{KDP}(4)$ and $\mathrm{Cu}-\mathrm{KDP}(5)$ as well as from KDP references.

The characterization of compound is carried out from X-ray diffraction powder data. The intensities of the diffractograms are

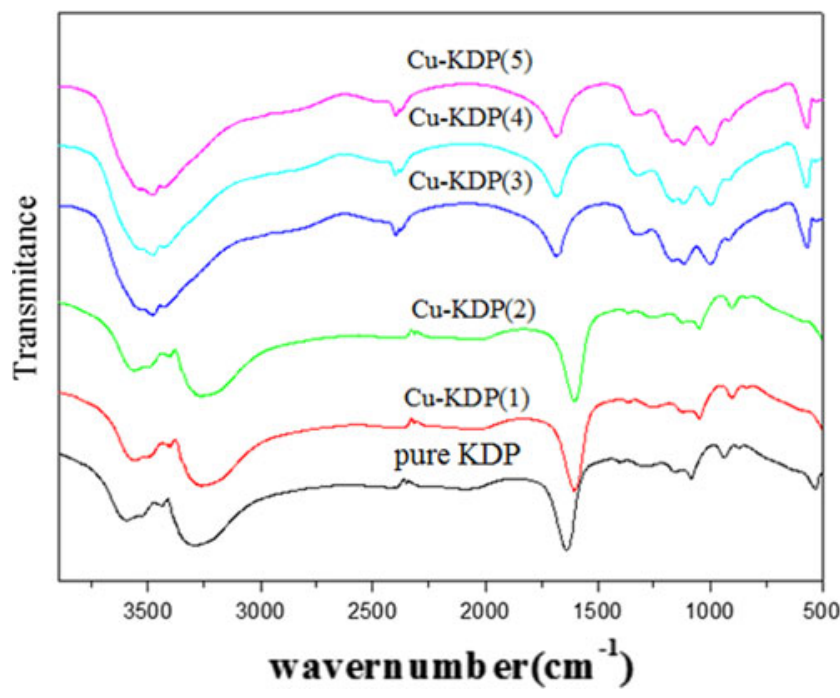

Fig. 5 FT-IR spectra recorded for the pure KDP, Cu-KDP (1), Cu-KDP (2), $\mathrm{Cu}-\mathrm{KDP}(3), \mathrm{Cu}-\mathrm{KDP}(4)$ and $\mathrm{Cu}-\mathrm{KDP}(5)$ at room temperature

collected by using a diffractometer Bruker-AXS, type D8 with $\mathrm{CuK} \alpha$ radiation $\left(\lambda\left(\mathrm{K}_{\alpha 1}\right)=1.54060 \AA, \lambda\left(\mathrm{K}_{\alpha 2}\right)=1.54443 \AA\right)$. Diffraction intensities are measured between $10^{\circ}$ and $60^{\circ}$, with a $2 \theta$ step of $0.02^{\circ}$ for $2 \mathrm{~s}$ per point. The data are collected at room temperature. The unit cell parameters calculated by using the patterns matching the routine of the FULPROOF program [28] are $a=7.45 \AA$ and $b=6.974 \AA$. Figure 2 shows the X-ray diffraction (XRD) pattern of $\mathrm{Cu}-\mathrm{KDP}$ (5). All the reflection peaks of the XRD pattern of the sample are indexed in a single-phase tetragonal KDP structure with I $\overline{4}$ 2d space group [29].

Thermogravimetric (TGA) and differential thermal analysis (DTA) are performed on polycrystalline with a TGA/DTA Q600 STD TA Instruments apparatus (sample with Pt crucibles,

Table 2 Raman spectra of pure KDP, Cu-KDP (1), Cu-KDP (2), Cu-KDP (3), Cu-KDP (4) and Cu-KDP (5)

\begin{tabular}{|c|c|c|c|c|c|c|}
\hline Pure KDP & $\mathrm{Cu}-\mathrm{KDP}(1)$ & $\mathrm{Cu}-\mathrm{KDP}(2)$ & $\mathrm{Cu}-\mathrm{KDP}(2)$ & $\mathrm{Cu}-\mathrm{KDP}(2)$ & $\mathrm{Cu}-\mathrm{KDP}(2)$ & Assignment \\
\hline $116 \mathrm{~m}$ & $115 \mathrm{~m}$ & $115 \mathrm{~m}$ & $118 \mathrm{~m}$ & $118 \mathrm{~m}$ & $118 \mathrm{~m}$ & Lattice vibrations \\
\hline $154 \mathrm{~m}$ & $152 \mathrm{~m}$ & $154 \mathrm{~m}$ & $159 \mathrm{~m}$ & $157 \mathrm{~m}$ & $160 \mathrm{~m}$ & \\
\hline $187 \mathrm{w}$ & $187 \mathrm{w}$ & $187 \mathrm{w}$ & $188 \mathrm{w}$ & $188 \mathrm{w}$ & $189 \mathrm{w}$ & \\
\hline \multirow[t]{3}{*}{$191 w$} & \multirow[t]{3}{*}{$191 \mathrm{w}$} & \multirow[t]{3}{*}{$191 w$} & $193 w$ & $193 w$ & $193 w$ & $v(\mathrm{O}-\mathrm{H} \equiv \mathrm{O})$ \\
\hline & & & $235 \mathrm{~m}$ & $234 \mathrm{~m}$ & $235 \mathrm{~m}$ & $\mathrm{Cu}-\mathrm{O}$ \\
\hline & & & $253 \mathrm{~m}$ & $253 \mathrm{~m}$ & $253 \mathrm{~m}$ & \\
\hline $358 \mathrm{~m}$ & $357 \mathrm{~m}$ & $357 \mathrm{~m}$ & $352 \mathrm{~m}$ & $355 \mathrm{~m}$ & $354 \mathrm{~m}$ & $\delta_{\mathrm{s}}\left[\mathrm{PO}_{2}, \mathrm{P}(\mathrm{OH})_{2}\right]$ \\
\hline $391 w$ & $390 \mathrm{w}$ & $390 \mathrm{w}$ & $389 w$ & $388 w$ & $388 w$ & $\gamma_{\tau} \mathrm{P}(\mathrm{OH})_{2}$ \\
\hline $474 \mathrm{~m}$ & $469 \mathrm{~m}$ & $469 \mathrm{~m}$ & $473 \mathrm{~m}$ & $475 w$ & $473 \mathrm{~m}$ & $\delta_{\mathrm{r}}\left[\mathrm{PO}_{2}, \mathrm{P}(\mathrm{OH})_{2}\right]$ \\
\hline $536 \mathrm{w}$ & $529 \mathrm{w}$ & $529 \mathrm{w}$ & $530 \mathrm{w}$ & $532 \mathrm{w}$ & $533 w$ & $\gamma_{\omega} \mathrm{P}(\mathrm{OH})_{2}$ \\
\hline $565 \mathrm{~m}$ & $563 \mathrm{~m}$ & $563 w$ & $561 \mathrm{w}$ & $561 \mathrm{w}$ & $561 \mathrm{w}$ & $\delta_{\mathrm{sc}}\left[\mathrm{PO}_{2}, \mathrm{P}(\mathrm{OH})_{2}\right]$ \\
\hline $916 \mathrm{vs}$ & $916 \mathrm{vs}$ & $916 \mathrm{vs}$ & $914 \mathrm{vs}$ & $914 \mathrm{vs}$ & $914 \mathrm{vs}$ & $\nu_{\mathrm{s}} \mathrm{P}(\mathrm{OH})_{2}$ \\
\hline $1,817 \mathrm{~m}$ & $1,810 \mathrm{~m}$ & $1,815 \mathrm{~m}$ & $1,759 \mathrm{w}$ & $1,753 \mathrm{~m}$ & $1,758 \mathrm{~m}$ & Band C \\
\hline $2,370 \mathrm{~m}$ & $2,369 \mathrm{~m}$ & $2,368 \mathrm{~m}$ & $2,373 \mathrm{~m}$ & $2,379 \mathrm{~m}$ & $2,383 \mathrm{~m}$ & $\nu_{\mathrm{O}-\mathrm{H}}($ band $\mathrm{B})$ \\
\hline $2,728 \mathrm{~m}$ & $2,719 \mathrm{~m}$ & $2,720 \mathrm{~m}$ & $2,829 \mathrm{~m}$ & $2,831 \mathrm{~m}$ & $2,830 \mathrm{~m}$ & $\nu_{\mathrm{O}-\mathrm{H}}($ band $\mathrm{A})$ \\
\hline
\end{tabular}

$v s$ very strong, $s$ strong, $m$ medium, $w$ weak 
Table 3 Infrared spectra of pure KDP, Cu-KDP (1), Cu-KDP (2), Cu-KDP (3), Cu-KDP (4) and Cu-KDP (5)

\begin{tabular}{|c|c|c|c|c|c|c|}
\hline Pure KDP & $\mathrm{Cu}-\mathrm{KDP}(1)$ & $\mathrm{Cu}-\mathrm{KDP}(2)$ & $\mathrm{Cu}-\mathrm{KDP}(2)$ & $\mathrm{Cu}-\mathrm{KDP}(2)$ & $\mathrm{Cu}-\mathrm{KDP}(2)$ & Assignment \\
\hline $494 m$ & $492 \mathrm{~m}$ & $490 \mathrm{~m}$ & $466 \mathrm{~m}$ & $466 \mathrm{~m}$ & $463 \mathrm{~m}$ & $\delta_{\mathrm{r}}\left[\mathrm{PO}_{2}, \mathrm{P}(\mathrm{OH})_{2}\right]$ \\
\hline $549 \mathrm{~m}$ & $546 \mathrm{~m}$ & $544 \mathrm{~m}$ & $569 \mathrm{~m}$ & $568 \mathrm{~m}$ & $568 \mathrm{~m}$ & $\gamma_{\omega} \mathrm{P}(\mathrm{OH})_{2}$ \\
\hline $829 m$ & $829 \mathrm{~m}$ & $832 \mathrm{~m}$ & $886 \mathrm{~m}$ & $887 \mathrm{~m}$ & $886 \mathrm{~m}$ & $\nu_{\mathrm{s}} \mathrm{P}(\mathrm{OH})_{2}$ \\
\hline $934 \mathrm{~m}$ & $928 \mathrm{~m}$ & $926 \mathrm{~m}$ & $998 \mathrm{~m}$ & $996 \mathrm{~m}$ & $996 \mathrm{~m}$ & $\nu_{\text {as }} \mathrm{P}(\mathrm{OH})_{2}$ \\
\hline $1,083 w$ & $1,079 w$ & $1,071 \mathrm{w}$ & $1,108 \mathrm{w}$ & $1,108 \mathrm{w}$ & $1,106 \mathrm{w}$ & $\delta_{\mathrm{s}}\left(\mathrm{PO}_{2}\right)$ \\
\hline $1,151 \mathrm{w}$ & $1,149 \mathrm{w}$ & $1,134 \mathrm{w}$ & $1,169 \mathrm{w}$ & $1,168 \mathrm{w}$ & $1,168 \mathrm{w}$ & $\delta_{\mathrm{as}}\left(\mathrm{PO}_{2}\right)$ \\
\hline $1,288 w$ & $1,284 \mathrm{w}$ & $1,281 \mathrm{w}$ & $1,329 \mathrm{w}$ & $1,329 w$ & $1,326 \mathrm{w}$ & $\delta_{\mathrm{as}}(\mathrm{H})$ \\
\hline $1,635 \mathrm{~s}$ & $1,631 \mathrm{~s}$ & $1,629 \mathrm{~s}$ & $1,683 \mathrm{~s}$ & $1,682 \mathrm{~s}$ & $1,681 \mathrm{~s}$ & Band C \\
\hline $2,045 w$ & $2,038 \mathrm{vw}$ & $2,032 \mathrm{vw}$ & - & - & - & $\nu_{\mathrm{O}-\mathrm{H}}($ band $\mathrm{B})$ \\
\hline $2,293 \mathrm{vw}$ & $2,288 \mathrm{vw}$ & $2,285 \mathrm{vw}$ & - & - & - & \\
\hline $2,343 \mathrm{vw}$ & $2,339 \mathrm{vw}$ & $2,337 \mathrm{vw}$ & - & - & - & \\
\hline $2,386 \mathrm{vw}$ & $2,376 \mathrm{vw}$ & $2,373 \mathrm{vw}$ & $2,381 \mathrm{~m}$ & $2,383 \mathrm{~m}$ & $2,379 \mathrm{~m}$ & \\
\hline- & - & - & $2,398 \mathrm{~m}$ & $2,394 \mathrm{~m}$ & $2,394 \mathrm{~m}$ & \\
\hline $3,268 \mathrm{~s}$ & $3,264 \mathrm{~s}$ & $3,261 \mathrm{~s}$ & - & - & - & $\gamma(\mathrm{O}-\mathrm{H})$ \\
\hline- & - & - & $3,430 \mathrm{w}$ & $3,428 w$ & $3,428 w$ & \\
\hline $3,435 w$ & $3,430 \mathrm{w}$ & $3,425 \mathrm{w}$ & - & - & - & \\
\hline- & - & - & $3,483 \mathrm{w}$ & $3,480 \mathrm{w}$ & $3,483 w$ & \\
\hline $3,516 \mathrm{w}$ & $3,512 \mathrm{w}$ & $3,513 w$ & - & - & - & \\
\hline- & - & - & $3,565 \mathrm{w}$ & $3,565 \mathrm{w}$ & $3,565 \mathrm{w}$ & \\
\hline $3,600 \mathrm{~m}$ & $3,593 \mathrm{~m}$ & $3,592 \mathrm{~m}$ & - & - & - & \\
\hline
\end{tabular}

$v s$ very strong, $s$ strong, $m$ medium, $w$ weak

$\mathrm{Al}_{2} \mathrm{O}_{3}$ as a reference). Thermograms are collected on 28.65-mg samples in the $\mathrm{RT}-573 \mathrm{~K}$ range with a heating rate of $10 \mathrm{~K} / \mathrm{mn}$ under a dry nitrogen flow rate of $100 \mathrm{ml} / \mathrm{mn}$.

Raman spectra are measured with a LABRAMHR 800 triple monochromator. The slit widths are set to maintain a resolution of approximately $3 \mathrm{~cm}^{-1}$. The excitation light is $632.81 \mathrm{~nm}$ wavelength of $\mathrm{He}-\mathrm{Ne}(20 \mathrm{mV})$ laser. Measurements are carried out using a microscope in an open furnace (under air, at ambient pressure) heating from 303 to $513 \mathrm{~K}$. The heating rate is $10 \mathrm{~K} / \mathrm{mn}$, waiting for $1 \mathrm{~min}$ after stabilization of temperature, and collecting time for each spectrum is $10 \mathrm{~s}$.

The infrared absorption spectrum was recorded using a pellet of sample, which was prepared by mixing $1 \mathrm{mg}$ sample in a total weight (samples $+\mathrm{KBr}$ ) of $200 \mathrm{mg}$. A Perkin-Elmer FT-IR
Fig. 6 Correlation scheme of internal vibration of the $\left(\mathrm{H}_{2} \mathrm{PO}_{4}\right)^{-}$in tetragonal $\mathrm{Cu}-\mathrm{KDP}$

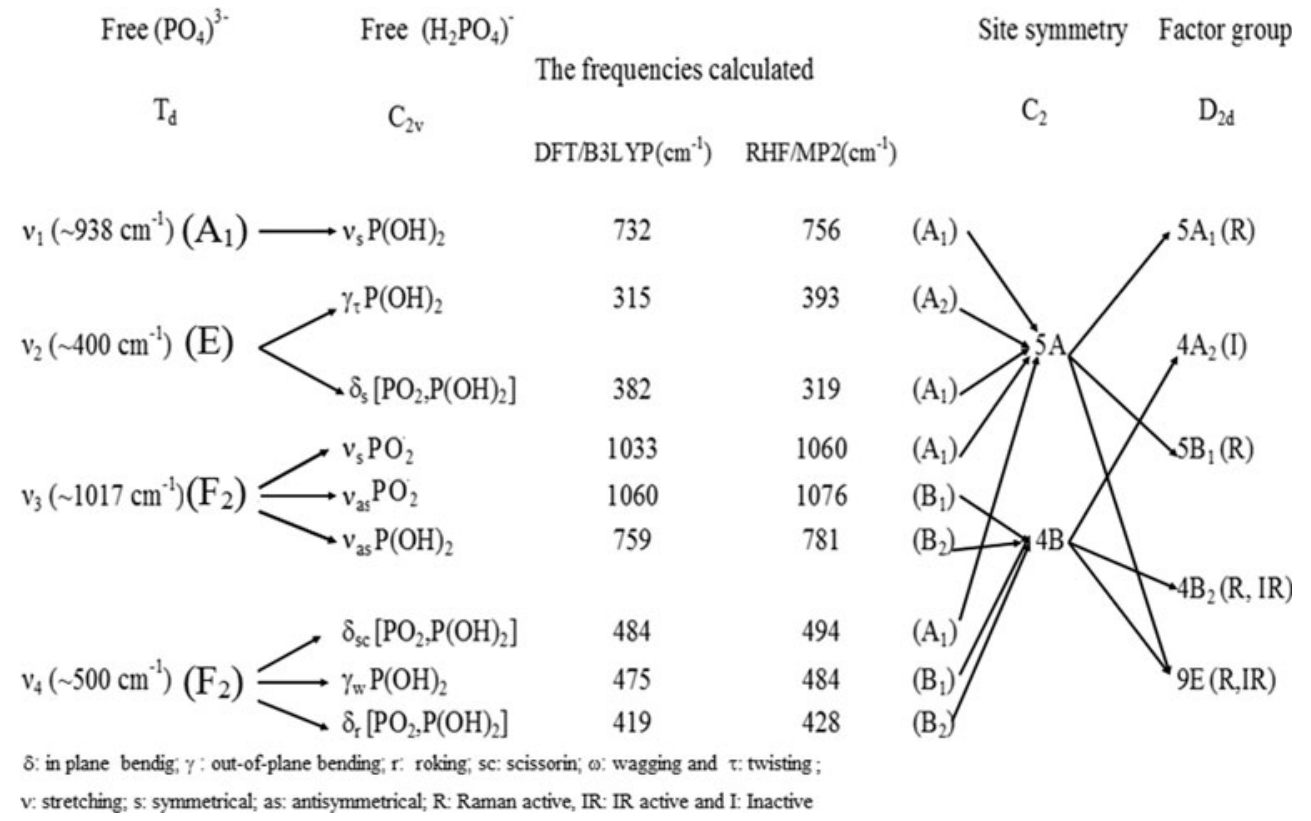




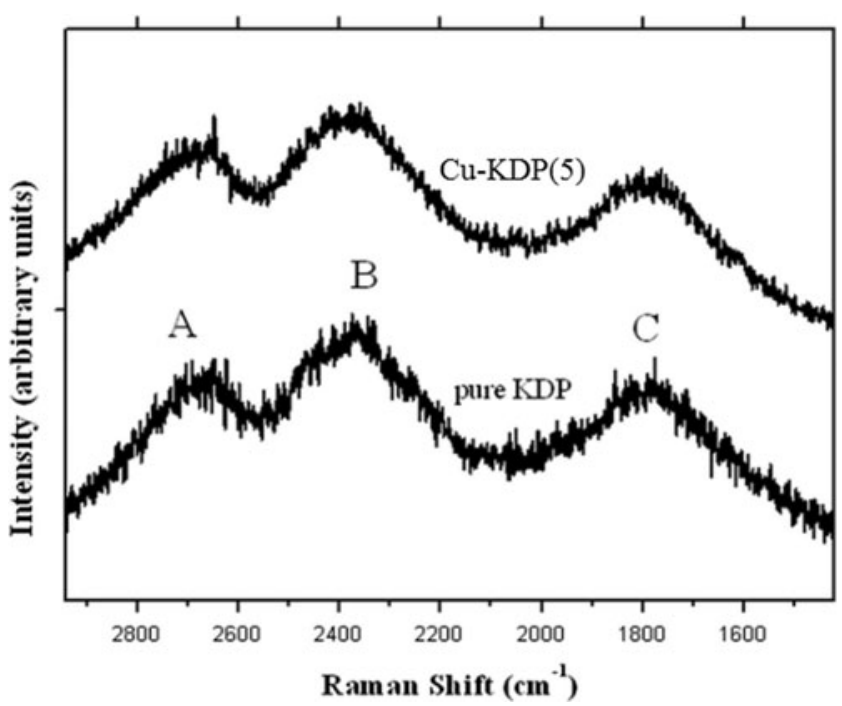

Fig. 7 ABC-type bands in the Raman spectrum for the pure and $\mathrm{Cu}-$ $\mathrm{KDP}(5)$ at room temperature

system PC spectrophotometer in the range of 4,000-400 $\mathrm{cm}^{-1}$ using 30 scans with $4-\mathrm{cm}^{-1}$ spectral resolution was used for this purpose. A reference pellet was prepared using $200 \mathrm{mg} \mathrm{KBr}$ and has been used to correct the background.

Table 4 Wavenumbers $\left(\mathrm{cm}^{-1}\right)$ of the bands in the Raman spectra of $\mathrm{Cu}-\mathrm{KDP}(5)$

\begin{tabular}{|c|c|c|c|}
\hline $\begin{array}{l}\text { II } \\
T=303 \mathrm{~K}\end{array}$ & $\begin{array}{l}\mathrm{I}(\mathrm{a}) \\
T=453 \mathrm{~K}\end{array}$ & $\begin{array}{l}\mathrm{I}(\mathrm{b}) \\
T=473 \mathrm{~K}\end{array}$ & Assignment \\
\hline - & $61 \mathrm{w}$ & $64 w$ & Lattice vibrations \\
\hline- & $73 w$ & - & \\
\hline - & $94 w$ & - & \\
\hline - & - & - & \\
\hline - & - & $106 \mathrm{w}$ & \\
\hline $118 \mathrm{~m}$ & - & - & \\
\hline - & $154 \mathrm{~m}$ & $155 \mathrm{~m}$ & \\
\hline $152 \mathrm{~m}$ & - & - & \\
\hline $182 \mathrm{~m}$ & - & - & $v(\mathrm{O}-\mathrm{H}-\mathrm{O})$ \\
\hline $193 \mathrm{~m}$ & - & - & $\mathrm{Cu}-\mathrm{O}$ \\
\hline $235 \mathrm{~m}$ & $229 m$ & $230 \mathrm{w}$ & \\
\hline \multirow[t]{3}{*}{$253 \mathrm{~m}$} & - & - & \\
\hline & & $286 \mathrm{~m}$ & \\
\hline & & & $\delta_{\mathrm{s}}\left[\mathrm{PO}_{2}, \mathrm{P}(\mathrm{OH})_{2}\right]$ \\
\hline $354 \mathrm{~m}$ & $364 \mathrm{~m}$ & $374 \mathrm{~m}$ & $\gamma_{\tau} \mathrm{P}(\mathrm{OH})_{2}$ \\
\hline $473 w$ & $429 w$ & $545 w$ & $\delta_{\mathrm{r}}\left[\mathrm{PO}_{2}, \mathrm{P}(\mathrm{OH})_{2}\right]$ \\
\hline $533 w$ & $507 \mathrm{w}$ & $604 w$ & $\gamma_{\omega} \mathrm{P}(\mathrm{OH})_{2}$ \\
\hline \multirow[t]{2}{*}{$561 \mathrm{~s}$} & $572 \mathrm{~s}$ & $620 \mathrm{vs}$ & $\delta_{\mathrm{sc}}\left[\mathrm{PO}_{2}, \mathrm{P}(\mathrm{OH})_{2}\right]$ \\
\hline & $901 \mathrm{~m}$ & & $\nu_{\mathrm{s}} \mathrm{P}(\mathrm{OH})_{2}$ \\
\hline \multirow[t]{3}{*}{$914 \mathrm{~s}$} & $960 \mathrm{~s}$ & $922 \mathrm{vs}$ & \\
\hline & & $1,100 \mathrm{~m}$ & $\nu_{\text {as }}\left(\mathrm{PO}_{2}\right)$ \\
\hline & $1,175 \mathrm{~m}$ & & \\
\hline
\end{tabular}

$v s$ very strong, $s$ strong, $m$ medium, $w$ weak

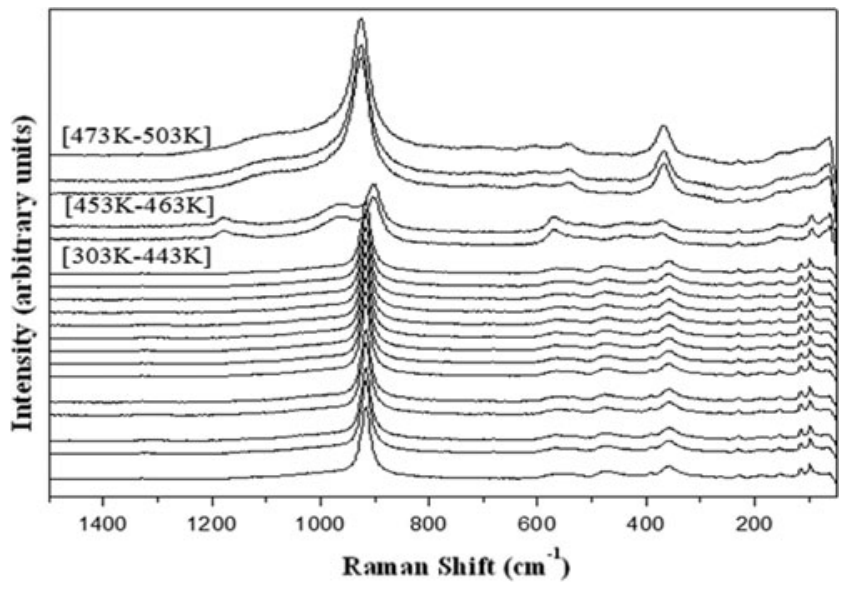

Fig. 8 Raman spectra of Cu-KDP (5) single crystal in the temperature range $303-503 \mathrm{~K}$

Electrical conductivity measurements were carried out by means of impedance spectroscopy in dehydrated $\mathrm{N}_{2}$ atmosphere in the temperature range from 315 to $495 \mathrm{~K}$. The experiments were done out with ion-blocking sputtered Pt electrodes in a two-probe cell. A frequency response analyser (Solartron 1260) and a dielectric interface (Solartron 1296) were used in the frequency domain from $1 \mathrm{~Hz}$ to $10 \mathrm{MHz}$. Before each measurement, electrochemical system linearity and stability were checked. An AC voltage of $300 \mathrm{mV}$ is used, with a waiting time of $25 \mathrm{~min}$ for each $23-{ }^{\circ} \mathrm{C}$ step (thermal equilibration). Impedance diagrams plotted in the Nyquist complex plane were fitted with a series combination of Rs and Rp//CPE elements of the Z-view 3.2c software assigned [30].

\section{Results and discussion}

DTA and TGA studies

The thermal measurement (Fig. 3) of Cu-KDP (5) reveals the presence of two high-temperature phase transitions at $462 \mathrm{~K}$ $\left(189{ }^{\circ} \mathrm{C}\right)$ and $473 \mathrm{~K}\left(200{ }^{\circ} \mathrm{C}\right)$. Thermal gravimetric analysis shows that the transition is not related to decomposition. Significant weight loss occurred from $498 \mathrm{~K}\left(225^{\circ} \mathrm{C}\right)$.

\section{Infrared and Raman spectroscopy}

The KDP crystal at room temperature may be considered as consisting of $\mathrm{K}^{+}$and $\left(\mathrm{H}_{2} \mathrm{PO}_{4}\right)^{-}$ions belonging to the space group I $\overline{4} 2$ d. The $\mathrm{H}_{2} \mathrm{PO}_{4}$ groups together with atoms of $\mathrm{K}$ lying between them on axis $z$ (c) create columns shifted one against the other at $\mathrm{c} / 4$ along the direction $z$. Each $\mathrm{PO}_{4}$ group is linked with four neighbouring $\mathrm{PO}_{4}$ groups by four hydrogen bonds lying almost exactly in the planes perpendicular to the $z$-axis. The local symmetry of the $\left(\mathrm{H}_{2} \mathrm{PO}_{4}\right)$ tetrahedron is $\mathrm{C}_{2}$, 


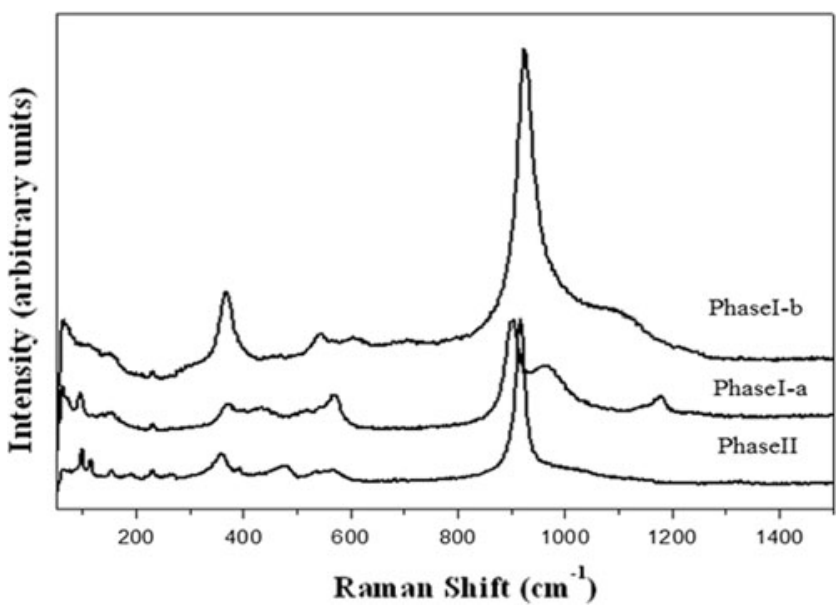

Fig. 9 Raman spectra of Cu-KDP (5) material in phase II, phase I-a and phase I-b

not $\mathrm{S}_{4}$, which is the average site symmetry in the paraelectric phase, as determined by X-ray analysis [5].

At room temperature, the Raman spectrum of $\mathrm{Cu}-\mathrm{KDP}$ is similar to that of $\operatorname{KDP}[26,31]$. Figures 4 and 5 show the infrared and Raman spectra of pure KDP, $\mathrm{Cu}-\mathrm{KDP}(1), \mathrm{Cu}-$ KDP (2), Cu-KDP (3), Cu-KDP (4) and Cu-KDP (5). Spectral data and proposed assignment are listed in Tables 2 and 3. The analysis is based on the classical identification of external modes implying the whole lattice network, internal modes of the $\left(\mathrm{H}_{2} \mathrm{PO}_{4}\right)^{-}$tetrahedra and stretching and bending modes of $\mathrm{OH}$ bonds. The attribution is done with respect to the KDP attribution taken from $[4,31,32]$ and calculated frequencies of free $\left(\mathrm{H}_{2} \mathrm{PO}_{4}\right)^{-}$ions.

To calculate the frequencies of the vibrational modes of the $\mathrm{H}_{2} \mathrm{PO}_{4}$ entity, ab initio RHF/MP2 and DFT/B3LYP electronic structure calculations were carried out using the TZV standard basis set augmented by one diffuse and one polarization functions implemented in the GAMESS program [33]. To identify different vibrational modes, the MOLDEN package [34] was used. Vibrational levels obtained by RHF/MP2 and DFT/B3LYP calculation on free $\left(\mathrm{H}_{2} \mathrm{PO}_{4}\right)^{-}$and in the experimental result are compared with those measured [32] in aqueous solution.
Figure 6 shows the correlation of the free $\left(\mathrm{H}_{2} \mathrm{PO}_{4}\right)^{-}$group vibrations in $\mathrm{C}_{2 \mathrm{v}}$ internal vibrations in $\mathrm{C}_{2}$ factor group symmetry through the $\mathrm{D}_{2 \mathrm{~d}}$ one in the crystal.

The spectroscopic characteristics of the free $\mathrm{H}_{2} \mathrm{PO}_{4}$ ion with pseudo-symmetry $\mathrm{C}_{2 \mathrm{v}}$ can be deduced from the free tetrahedral $\mathrm{PO}_{4}$ entity. The two stretching modes $v_{1}(\sim 938$ $\left.\mathrm{cm}^{-1}\right)$ and $\nu_{3}\left(\sim 1,017 \mathrm{~cm}^{-1}\right)$ lead to four stretching modes (two modes $\nu\left(\mathrm{PO}_{2}\right)$, one antisymmetrical $\left(\mathrm{B}_{1}\right)$ at about $1,033 \mathrm{~cm}^{-1}$ and one symmetrical $\left(A_{1}\right)$ at $1,060 \mathrm{~cm}^{-1}$, and two $\nu\left(\mathrm{P}(\mathrm{OH})_{2}\right)$ around 732 and $759 \mathrm{~cm}^{-1}$ with symmetry $\mathrm{A}_{1}$ and $\mathrm{B}_{2}$, respectively) (Fig. 6). The bending modes, arising from $\nu_{2}$ and $\nu_{4}$, are expected at around 315 and $382 \mathrm{~cm}^{-1}$ and at 419,475 and $484 \mathrm{~cm}^{-1}$, respectively. Finally, the three calculated frequencies involving the $\mathrm{OH}$ group are 1,093, 1,299 and $3,830 \mathrm{~cm}^{-1}$. All of these vibrations theoretically appear in Raman spectra, and only the vibrations with symmetry mode $A_{1}, B_{1}$, and $B_{2}$ appear in IR spectra.

As shown in Figs. 4 and 5, the additive has a considerable influence in the Raman and IR spectra. For example, the bands which appear at 3,600 and $3268 \mathrm{~cm}^{-1}$ in pure KDP and assigned to free $\mathrm{O}-\mathrm{H}$ stretching [19] are absent from $\mathrm{Cu}-$ KDP (3). The absence of these peaks supports the adsorption of $\mathrm{Cu}^{2+}$ in the surfaces of the crystal. The deviation of IR frequencies for $\mathrm{O}-\mathrm{H}$ stretching observed at 3,435 and $3,516 \mathrm{~cm}^{-1}$ in pure KDP [19] to higher frequencies, respectively, at 3,483 and $3,565 \mathrm{~cm}^{-1}$ in $\mathrm{Cu}-\mathrm{KDP}$ (3) reflects the possible entry of $\mathrm{Cu}^{2+}$ cations in the lattice site of the KDP crystal. The increasing frequency of $\mathrm{O}-\mathrm{H}$ stretching indicates clearly the weakening of the bond strength between oxygen and hydrogen and the interaction of dopant with $\mathrm{P}-\mathrm{O}-\mathrm{H}$ group of KDP. The entry of $\mathrm{Cu}^{2+}$ ions into the lattice of the tetragonal KDP crystal can be also confirmed by the variation of Raman and IR frequencies for stretching and bending vibrations $\nu\left(\mathrm{PO}_{2}\right), \nu \mathrm{P}(\mathrm{OH})_{2}, \delta\left(\mathrm{H}_{2} \mathrm{PO}_{4}\right)$ and $\gamma\left(\mathrm{H}_{2} \mathrm{PO}_{4}\right)$ (Tables 2 and 3).

In the Raman spectra, we observed two new bands centred at 253 and $235 \mathrm{~cm}^{-1}$ in the spectrum of Cu-KDP (3). We observed that these two peaks become more intense for $\mathrm{Cu}-\mathrm{KDP}$ (5). These two bands are characteristic of the $\mathrm{Cu}-\mathrm{O}$ bond [35].

External modes result from translational and vibrational modes of anions and translational ones of cations. The vibrational
Fig. 10 The temperature dependence of the wavenumbers of some bands observed in the Raman spectra of the $\mathrm{Cu}-\mathrm{KDP}(5)$
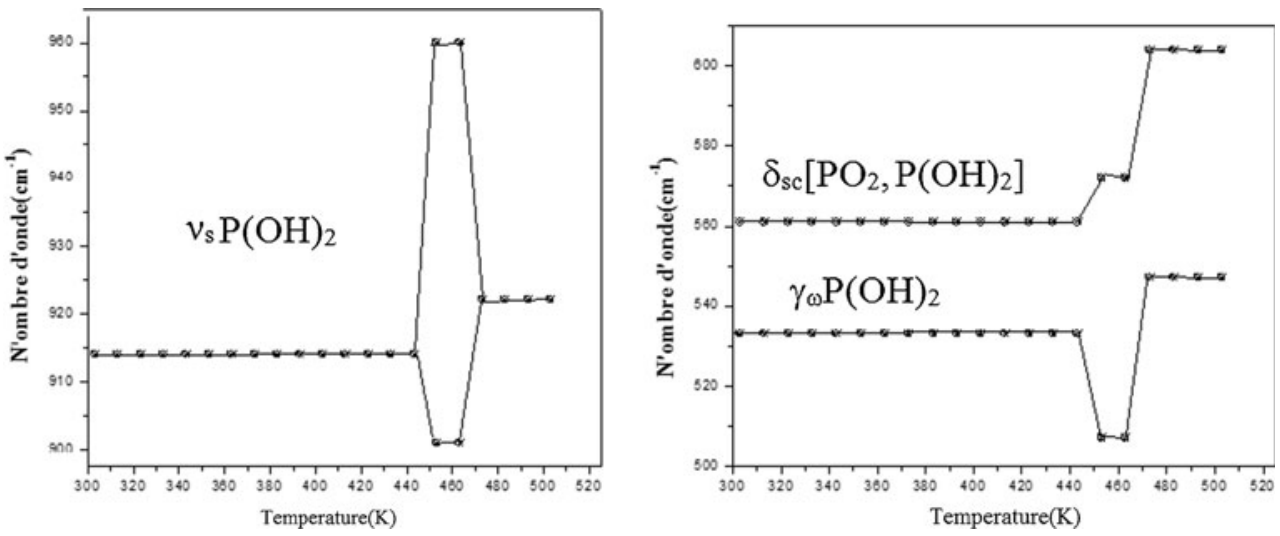
and translational modes of anions can be seen as hydrogen bond stretchings and bendings inside the layers. They are observed below $300 \mathrm{~cm}^{-1}$ for KDP families [36]. According to Som et al., the lines observed at 116 and $154 \mathrm{~cm}^{-1}$ in pure KDP and at 118 and $155 \mathrm{~cm}^{-1}$ in $\mathrm{Cu}-\mathrm{KDP}$ may be assigned to $\mathrm{K}-\mathrm{PO}_{4}$ translatory vibrations along the c-axis [37]. The $187 \mathrm{~cm}^{-1}$ in $\mathrm{Cu}-\mathrm{KDP}$ (3) band can be assigned to the $\mathrm{H}_{2} \mathrm{PO}_{4}$ rotational band. The band observed at $193 \mathrm{~cm}^{-1}$ from $\mathrm{Cu}-\mathrm{KDP}$ (3) can be attributed to the stretching $\nu(\mathrm{O}-\mathrm{H} \equiv \mathrm{O})$ bridge vibration. This band is observed at about $191 \mathrm{~cm}^{-1}$ in Raman spectra of pure KDP.

The ABC-type broad bands of high-frequency $\mathrm{H}$ vibrations have been interpreted as $\mathrm{O}-\mathrm{H}$ stretching modes in Fermi resonance with combination involving mainly $\mathrm{O}-\mathrm{H}$ bending vibrations [38] or in terms of strong coupling between fast $\mathrm{O}-\mathrm{H}$ and slow $\mathrm{O}=\mathrm{O}$ stretching modes [38]. These spectral characteristics have been observed in a variety of strong hydrogen-bonded solids having O-O distances varying from 2.45 to $2.66 \AA$ [39]. In the present case, the ABC-type bands appear in the Raman spectrum of pure KDP at 2,728, 2,370 and $1,817 \mathrm{~cm}^{-1}$, respectively (Fig. 7). These bands appear at about 2,830, 2,383 and $11,758 \mathrm{~cm}^{-1}$, respectively, in Cu-KDP (5) (Fig. 7). The substantial change in the position of these bands reflects the possible incorporation of $\mathrm{Cu}^{2+}$ in the lattice site of KDP crystal.

In conclusion, in a low concentration of copper $(\mathrm{Cu}-\mathrm{KDP}$ (1) and $\mathrm{Cu}-\mathrm{KDP}(2)$ ), all of the copper is practically substituted in volume, whereas in the high concentrations the copper is absorbed in both volume and the surface.

It is reported that at an increase of the temperature above $453 \mathrm{~K}$, a monoclinic phase is obtained. The tetragonal $\rightarrow$ monoclinic transition usually occurs at a temperature between 453 and $493 \mathrm{~K}$; the measured value depends strongly on sample preparation $[8,40]$. In the monoclinic phase, space group $\mathrm{P} 2{ }_{1} / \mathrm{m}\left(\mathrm{C}_{2 \mathrm{~h}}\right)$, the atomic distribution and lattice parameters at $463 \mathrm{~K}$ are obtained $(a=7.590 \AA$, $b=6.209 \AA, c=4.530 \AA, \beta=107.36^{\circ}$ ) [8].

In Fig. 8, the increase of temperature from 303 to $503 \mathrm{~K}$ shows some modifications in the Raman spectra of $\mathrm{Cu}-\mathrm{KDP}$ (5) but

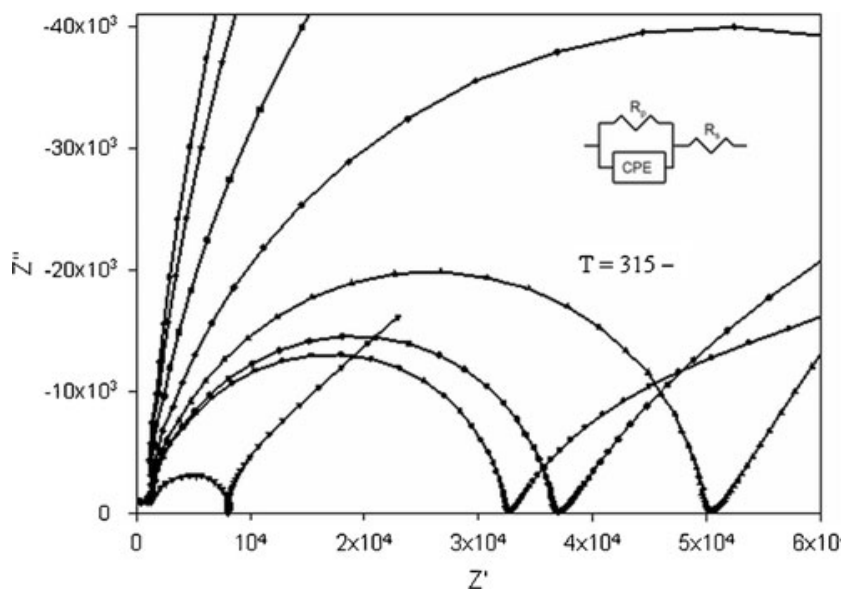

Fig. 11 Complex plane plots of $\mathrm{Cu}-\mathrm{KDP}(5)$ at various temperatures

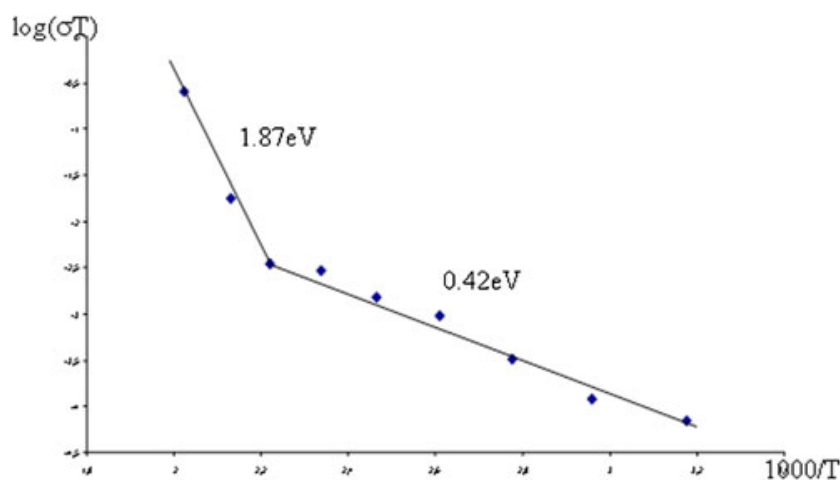

Fig. 12 Conductivity plots $\log (\sigma T)=f(1,000 / T)$ for $\mathrm{Cu}-\mathrm{KDP}(5)$ compound

without any well-known bands due to $\mathrm{P}_{2} \mathrm{O}_{7}$ entities [40]. These bands might indicate some dehydration (Table 4). Two-phase transitions at 453 and $473 \mathrm{~K}$ are related to $\mathrm{Cu}-\mathrm{KDP}$ (5) (Fig. 9).

The increase of temperature in $\mathrm{Cu}-\mathrm{KDP}$ (5), between 303 and $503 \mathrm{~K}$, causes the disappearance of lines at low frequency, corresponding to the lattice modes and the band at $193 \mathrm{~cm}^{-1}$, attributed to the stretching $\mathrm{O}==\mathrm{O}$ bridge vibrations. The appearance in $\mathrm{Cu}-\mathrm{KDP}(5)$ spectrum of a line at $61 \mathrm{~cm}^{-1}$ and another at $1,175 \mathrm{~cm}^{-1}$ corresponds to $\nu_{\mathrm{as}}\left(\mathrm{PO}_{2}\right)$ vibrations. Also, there are substantial changes in the position and intensity of some bands corresponding to the internal vibrations of $\mathrm{H}_{2} \mathrm{PO}_{4}$.

The most important change concerns the Raman line associated to $\nu_{\text {as }} \mathrm{P}(\mathrm{OH})_{2}$ mode. This strong line observed at $914 \mathrm{~cm}^{-1}$ at room temperature splits to two Raman lines near 901 and $960 \mathrm{~cm}^{-1}$ for the temperature between 453 and $463 \mathrm{~K}$ and reappears (from $473 \mathrm{~K}$ ) with a single strong line at $922 \mathrm{~cm}^{-1}$. The frequency of this vibration, $\nu_{\text {as }} \mathrm{P}(\mathrm{OH})_{2}$, estimated by Joost Vande Vondele et al. [32] from the calculation of free $\mathrm{H}_{2} \mathrm{PO}_{4}$ and in aqueous solution are 795 and $944 \mathrm{~cm}^{-1}$, respectively.

Appreciable changes are also observed for lines at $1,175 \mathrm{~cm}^{-1}$ due to $\nu_{\text {as }}\left(\mathrm{PO}_{2}\right)$ vibrations. This line appears between 453 and $473 \mathrm{~K}$ and disappears from $483 \mathrm{~K}$.

A plot of the temperature behaviour of some Raman wavenumber is shown in Fig. 10, which unambiguously proves the existence of singularities in the temperature range 303$503 \mathrm{~K}$. From these curves, the temperature of the $\mathrm{II} \rightarrow \mathrm{I}$ (a) transition is estimated at 453 and $473 \mathrm{~K}$ for $\mathrm{I}-\mathrm{a} \rightarrow \mathrm{I}-\mathrm{b}$ transition.

Table 5 Selected transport properties of $\mathrm{Cu}-\mathrm{KDP}$. Activation energies for proton conductivity determined from fit of $\sigma=A / T \exp \left(-E_{\mathrm{a}} / K T\right)$ over the temperature range stated. Conductivity given for the temperature listed

\begin{tabular}{lllll}
\hline Phase & $E_{\mathrm{a}}(\mathrm{eV})$ & $T$ range $(\mathrm{K})$ & Sigma $\left(\Omega^{-1} \mathrm{~cm}^{-1}\right)$ & $T(\mathrm{~K})$ \\
\hline $\mathrm{I}(\mathrm{a})$ & 0.42 & $315-450 \mathrm{~K}$ & $2.2 \times 10-$ & 315 \\
$\mathrm{I}(\mathrm{b})$ & 1.87 & $450-494 \mathrm{~K}$ & $3.7 \times 10^{-5}$ & 472 \\
\hline
\end{tabular}




\section{Dielectric properties}

Some complex impedance diagrams $-Z^{\prime \prime}$ versus $Z^{\prime}$ at various temperatures are given in Fig. 10 and show that $\mathrm{Cu}-\mathrm{KDP}$ (5) follows the Cole-Cole law. The bulk ohmic resistance relative to experimental temperature is the intercept on the real axis of the zero-phase angle extrapolation of the highest frequency curve.

In Fig. 11, the equivalent circuit of the crystal under the ac electric field at lower temperatures can be modelled well as a solution resistance $R_{\mathrm{s}}$ in series with the parallel combination of a polarization resistance $R_{\mathrm{P}}$ with a constant phase angle element (cpe).

The conductivity of $\mathrm{Cu}-\mathrm{KDP}$ (5) is shown in Arrhenius curve (Fig. 12). Only one transition, at $\mathrm{Ttr}=450 \mathrm{~K}$, of the two transitions noted by the calorimetric and Raman studies is apparent in the conductivity results. This transition leads to a sharp increase of the conductivity. The second transition is not observed because it produces a small impact on the transport properties.

The activation energies are obtained as $E_{\mathrm{a}}=0.42$ and $1.87 \mathrm{eV}$ above and below $\mathrm{Tp}=450 \mathrm{~K}$ for the ionic hopping of mobile ions $\left(\mathrm{H}^{+}\right)$(Table 5). In the KDP material, the activation energies are 0.42 and $0.68 \mathrm{eV}$ for the temperature above and below $453 \mathrm{~K}$, respectively. In $\mathrm{KH}_{2} \mathrm{AsO}_{4}$, the activation energies are 0.40 and $0.59 \mathrm{eV}$ for the temperature above and below $453 \mathrm{~K}$ [41].

It is noteworthy that the superprotonic $\mathrm{Cu}-\mathrm{KDP}(5)$ has a rather low activation energy for proton transport $(0.42 \mathrm{eV})$ and a significantly higher conductivity $\left(2.2 \times 10^{-7} \Omega^{-1} \mathrm{~cm}^{-1}\right)$ for the polycrystalline pellet compared to the pure KDP $\left(10^{-10} \Omega^{-1} \mathrm{~cm}^{-1}\right)[5,42]$. It is possible that the higher conductivity is due to the proton defects in $\mathrm{Cu}-\mathrm{KDP}$ caused by the substitution of $\mathrm{K}^{+}$by $\mathrm{Cu}^{2+}$.

\section{General conclusions}

The high temperature phenomena of $\mathrm{Cu}-\mathrm{KDP}$ are not related to chemical change such as thermal decomposition but related to the physical change of the structural phase transition. Doping KDP with $\mathrm{Cu}^{2+}$ significantly modifies its electric properties. The transport properties of protons in such crystals may be treated in terms of proton defects.

Acknowledgments Many thanks to Unité de sepectroscopie Raman FSS Sfax for the measurements of Raman spectra. The authors wish to express their gratitude to Prof. Mohamed Bahri from the Faculty of Science, Sfax, Tunisia, for the calculation of the frequencies of the $\left(\mathrm{H}_{2} \mathrm{PO}_{4}\right)^{-}$group.

Open Access This article is distributed under the terms of the Creative Commons Attribution License which permits any use, distribution, and reproduction in any medium, provided the original author(s) and the source are credited.

\section{References}

1. Park J-H, Kim C-S, Choi B-C, Moon BK, Seo H-J (2003) Physical properties of $\mathrm{CsH}_{2} \mathrm{PO}_{4}$ crystal at high temperatures. J Phys Soc Jpn 72:1592-1593

2. Li Z, Tang T (2010) High-temperature dehydration behavior and protonic conductivity of $\mathrm{RbH}_{2} \mathrm{PO}_{4}$ in humid atmosphere. J Mater Res Bull 45:1909-1915

3. Chen RH, Yen C-C, Shern CS, Fukami T (2006) Impedance spectroscopy and dielectric analysis in $\mathrm{KH}_{2} \mathrm{PO}_{4}$ single crystal. J Solid State Ionics 177:2857,2864

4. Serra KC, Melo FEA, Nendes Fllho J, Germano FA, Morelra JE (1988) Raman study of the tetragonal $\rightarrow$ monoclinic phase transition in KDP. J Solid State Commun 66:575-579

5. Kawahata Y, Tominaga Y (2008) Dynamical mechanism of ferroelectric phase transition in KDP/DKDP mixed crystals and distortion of $\mathrm{PO}_{4}$ tetrahedron. J Solid State Commun 145:218-222

6. Asakuma Y, Takeda S, Maeda K, Fukui K (2009) Kinetic and theoretical studies of metal ion adsorption in KDP solution. J Appl Surf Sci 255:4140-4144

7. Ponomareva VG, Martsinkevich VV, Chesalov YA (2011) Transport and thermal characteristics of $\mathrm{Cs}_{1-x} \mathrm{Rb}_{x} \mathrm{H}_{2} \mathrm{PO}_{4}$. J Electrochem 47:645-653

8. Botez CE, Carbajal D, Adiraju VAK, Tackett RJ, Chianelli RR (2010) Intermediate-temperature polymorphic phase transition in $\mathrm{KH}_{2} \mathrm{PO}_{4}$ : a synchrotron X-ray diffraction study. J Phys Chem Solids 71:1576-1580

9. Diosa JE, Vargas RA, Albinsson I, Mellander B-E (2004) Dielectric relaxation in single crystal $\mathrm{NH}_{4} \mathrm{H}_{2} \mathrm{PO}_{4}$ in the high-temperature regime. J Solid State Commun 132:55-58

10. Grunberg J, Levin S, Pelah I, Gerlich D (1972) High temperature phase transitions and metastability in KDP type crystals. J Phys Status Solidi 49:857

11. Lee J-K (1996) Hidden nature of the high-temperature phase transitions in crystals of $\mathrm{KH}_{2} \mathrm{PO}_{4}$ type: is it a physical change? J Phys Chem Solids 57:333

12. Ortiz E, Vargas A, Mellander B-E (1998) On the reported hightemperature phase transition in $\mathrm{KH}_{2} \mathrm{PO}_{4}$ - strong evidence of partial polymerization instead of a structural phase. J Phys Chem Solids 59:305-310

13. Itoh K, Matsubayashi T, Nakamura E, Motegi H (1975) X-ray study of high-temperature phase transitions in $\mathrm{KH}_{2} \mathrm{PO}_{4}$. J Phys Soc Jpn 39:843-844

14. Vargas RA, Chacon M, Trochez JC (1989) Specific heat of KDP near the tetragonal-monoclinic phase transition. J Solid State Ionics 34:93-95

15. Boysen DA, Haile SM (2004) Conductivity of potassium and rubidium dihydrogen phosphates at high temperature and pressure. J Chem Mater 16:693-697

16. Bronowska W (2006) High-temperature phenomena in $\mathrm{RbD}_{2} \mathrm{PO}_{4}$ and $\mathrm{CsH}_{2} \mathrm{PO}_{4}$ polymeric transformations or polymorphic phase transitions? J Mater Sci-Pol 24:230-236

17. Rajesh NP, Kannan V, Santhana Raghavan P, Ramasamy P, Lan CW (2002) Optical and microhardness studies of KDP crystals grown from aqueous solutions with organic additives. J Mater Lett 52:326-328

18. Ogorodnikov IN, Yakovlev VY, Shulgin BV, Satybaldieva MK (2002) Transient optical absorption of hole polarons in $\mathrm{ADP}\left(\mathrm{NH}_{4} \mathrm{H}_{2} \mathrm{PO}_{4}\right)$ and $\mathrm{KDP}\left(\mathrm{KH}_{2} \mathrm{PO}_{4}\right)$ crystals. J Phys Sol State 44:880-887

19. Kumaresan P, Moorthy Babu S, Anbarasan PM (2008) Growth and characterization of metal ions and dyes doped KDP single crystals for laser applications. J Mater Res Bull 43:1716-1723

20. Bredikhin VI, Galushkina GL, Kulagin AA, Kuznetsov SP, Malshakova OA (2003) Competing growth centers and step bunching in KDP crystal growth from solutions. J Cryst Growth 259:309-320

21. Alexandru HV, Antoh S (1996) Prismatic faces of KDP crystal, kinetic and mechanism of growth from solutions. J Cryst Growth 169:149-157 
22. Eremina TA, Kuznetsov VA, Eremin NN, Okhrimenko TM, Furmanova NG, Efremova EP, Rak M (2005) On the mechanism of impurity influence on growth kinetics and surface morphology of KDP crystals - II: experimental study of influence of bivalent and trivalent impurity ions on growth kinetics and surface morphology of KDP crystals. J Cryst Growth 273:586-593

23. Eremina TA, Eremin NN, Furmanova NG, Kuznetsov VA, Okhrimenko TM, Urusov VS (2001) Simulation of a defect region in KDP crystals doped with divalent iron ions. Comparison of defects induced by di- and trivalent metals. J Crystallogr Rep 46:75-80, Translated from Kristallografiya, Vol. 46(2001), pp. 82, 87

24. Eremina TA, Eremin NN, Kuznetsov VA, Furmanova NG, Urusov VSJ (2002) Simulation of defects formed by cations of bivalent and trivalent metals in the structure of potassium dihydrogen phosphate: a computational technique. J Crystallogr Rep 47:753-758, Translated from Kristallografiya. 47 (2002), pp. 819, 824

25. Toumi M, Mhiri T, Bulou A (2009) Raman spectroscopic study of $\mathrm{K}_{3} \mathrm{H}(\mathrm{SO} 4)_{2}$ (phases I and II) single crystals. J Vib Spectrosc 50:298-302

26. Lu G, Li C, Wang W, Wang Z, Guan J, Xia H (2005) Lattice vibration modes and thermal conductivity of potassium dihydrogen phosphate crystal studying by Raman spectroscopy. J Mater Sci Eng 116:47-53

27. Li G, Liping X, Su G, Zhuang X, Li Z, He Y (2005) Study on the growth and characterization of KDP-type crystals. J Cryst Growth 274:555-562

28. J. Rodriguez-Carvajal (2005) Program FULLPROF, version 2.6.1

29. Nelmes RJ (1987) Ferroelectrics 71:87

30. Help menu on equivalent circuits, instant curve fitting function and constant phase element in the ZView program (ver. 3.2c) from Scribner Associates, Inc

31. Videnova-Adrabińska V, Wojciechowski W, Baran J (1987) Polarized infrared and raman spectra of monoclinic $\mathrm{CsH}_{2} \mathrm{PO}_{4}$ single crystal and its deuterated homologue $\mathrm{CsD}_{2} \mathrm{PO}_{4}$ : part II. Internal vibrations of the $\mathrm{PO}_{4}$ ion. J Mol Struct 156:15-27
32. Vondele JV, Tröster P, Tavan P, Mathias G (2012) Vibrational spectra of phosphate ions in aqueous solution probed by firstprinciples molecular dynamics. J Phys Chem 116:2466-2474

33. Schmidt MW, Baldridge KK, Boatz JA, Elbert ST, Gordon MS, Jensen JH, Koseki S, Matsunaga N, Nguyen KA, Su SJ, Windus TL, Dupuis M, Montgomery JA (1993) General atomic and molecular electronic structure system. J Comput Chem 14:13471363

34. Schaftenaar G, Noordik JH (2000) Molden: a pre- and postprocessing program for molecular and electronic structures. J Comput Aided Mol Des 14:123,134

35. Vedeanu N, Cozar O, Ardelean I, Lendl B (2006) IR and Raman investigation of $\mathrm{x}\left(\mathrm{CuO} \cdot \mathrm{V}_{2} \mathrm{O}_{5}\right)(1-\mathrm{x})\left[\mathrm{P}_{2} \mathrm{O}_{5} \cdot \mathrm{CaF}_{2}\right]$ glass system. $\mathrm{J}$ Optoelectron Adv Mater 8:78,81

36. Lee K-S, Ko J-H, Moon J, Lee S, Jeon M (2008) Raman spectroscopic study of $\mathrm{LiH}_{2} \mathrm{PO}_{4}$. J Solid State Commun 145:487-492

37. Som T, Navati MS, Kulkarni VN (2001) Physico-chemical changes in ion-irradiated KDP. J Nucl Inst Methods Phys Res 179:551-556

38. Choi B-K (1995) High temperature phase transition and thermal decomposition of $\mathrm{KH}_{2} \mathrm{PO}_{4}$ crystals. J Phys Chem Solids 56:10231030

39. Taher LB, Chabchoub S, Smiri-Dogguy L (1999) Investigation of mixed alkaline earth phosphates. Synthesis and crystal structure of $\mathrm{CaBa}\left(\mathrm{HPO}_{4}\right)_{2}$ : a new mixed alkaline earth hydrogenmonophosphate. J Solid State Sci 1:15-24

40. Park J-H (2002) Separation of surface and bulk electrical conductivity in $\mathrm{KH}_{2} \mathrm{PO}_{4}$ and $\mathrm{KH}_{2} \mathrm{AsO}_{4}$ crystals at high temperatures. $\mathrm{J}$ Solid State Commun 123:291-294

41. Mathew M, Wong-Ng W (1995) Crystal structure of a new monoclinic form of potassium dihydrogen phosphate containing orthophosphacidiumion, $\left[\mathrm{H}_{4} \mathrm{PO}_{4}\right]^{+1}$. J Solid State Chem 114:219223

42. Kim SH, Lee KW, Kim I-M, Lee CE (2006) Impedance study near the ferroelastic transition in $\mathrm{TlH}_{2} \mathrm{PO}_{4}$. J Appl Phys Lett 88:192901 